\title{
PELAPORAN CORPORATE SOCIAL RESPONSIBILITY (CSR) UNIVERSITAS BERDASARKAN ANALISIS WEBSITE PADA NATIONAL UNIVERSITY OF SINGAPORE DAN UNIVERSITAS GADJAH MADA
}

\author{
Andreas Kurniadi W. G. \\ Jurusan Akuntansi / Universitas Surabaya \\ andreasdidi94@gmail.com \\ Dianne Frisko Koan \\ Jurusan Akuntansi / Universitas Surabaya \\ difrisko@accountingubaya.com
}

\begin{abstract}
Abstrak
National University of Singapore dan Universitas Gadjah Mada termasuk dalam sepuluh universitas terbaik di Asia Tenggara (ASEAN). CSR menjadi sangat penting untuk universitas di ASEAN karena merupakan tujuan utama membangun komunitas ASEAN dalam bidang sosio-kultur atau yang disebut sebagai ASEAN Socio-Cultural Community (ASCC). Penelitian ini bertujuan untuk mengetahui penerapan tata cara pelaporan Corporate Social Responsibility (CSR) untuk National University of Singapore dan Universitas Gadjah Mada yang sebelumnya belum pernah dibuat dan dipublikasikan. Metode penelitian yang digunakan adalah content analysis untuk situs konten website, berita, artikel, annual report, dan informasi terkait CSR Universitas periode 2010-2014. Standar ISO 26000 digunakan sebagai alat pengukuran dan menjadi framework untuk membentuk sebuah laporan kegiatan CSR yang terintegrasi. Hasil dalam penelitian ini berupa kerangka laporan CSR dari kedua universitas.
\end{abstract}

Kata kunci: Pelaporan CSR Universitas, CSR Universitas, ISO 26000, ASEAN.

\begin{abstract}
Both the university is among the top ten best universities in Southeast Asia (ASEAN). CSR is very important for universities in ASEAN as an ultimate goal of establishing an ASEAN Community in the field of socio-culture, or the so-called ASEAN SocioCultural Community (ASCC). The purpose of this paper is to determine the application of the reporting procedures of Corporate Social Responsibility (CSR) for the National University of Singapore and the University of Gadjah Mada that has not previously been made and published. The method used is content analysis for website content sites, news, articles, annual reports, and information related to CSR University 2010-2014. ISO 26000 standard is used as a measurement tool and become a framework to establish an integrated CSR activity report. The findings of the study represent as CSR Reporting Framework for this universities.
\end{abstract}

Keywords: CSR Reporting for University, University - CSR, ISO 26000, ASEAN. 


\section{PENDAHULUAN}

Peningkatan kepedulian program Corporate Social Responsibility (CSR) telah terjadi dalam beberapa dekade ini. Setiap orang harus berusaha untuk keberlanjutan hari besok (sustainable), yaitu fokus untuk memenuhi kebutuhan saat ini tanpa mengorbankan kemampuan untuk memenuhi kebutuhan kita di masa depan, serta menciptakan peluang untuk besok (Nejati dkk, 2011). Berdasarkan penelitian Moratis dkk (2005), CSR adalah "maatschappelijk verantwoord ondernemen" yang secara harafiah memiliki arti ganda dalam melakukan bisnis di masyarakat, yaitu dengan cara yang bertanggung jawab dan akuntabel kepada masyarakat sebagai sebuah organisasi. Hal ini juga dapat diaplikasikan untuk institusi perguruan tinggi (Christensen dkk, 2009).

Berdasarkan penelitian sebelumnya tentang program CSR telah dilaksanakan pada sepuluh (10) Universitas terbaik di dunia berdasarkan The World University ranking 2009 (Nejati dkk, 2011). Universitas- universitas ini telah menerapkan CSR di berbagai bidang dan lingkup. Universitas mengganggap CSR sebagai cara untuk membuktikan kredibilitas di tengah-tengah masyarakat. CSR merupakan cara branding dan pencitraan institusi. Hal ini menunjukkan bahwa peran perguruan tinggi telah berevolusi dari lembaga yang hanya terlibat dengan kegiatan akademik menjadi lembaga yang rentan terhadap kondisi masyarakat dan lingkungannya (Wijaya dan Krismiyati, 2014).

Program CSR di perguruan tinggi memiliki keunggulan ganda yaitu memberikan nilai yang baik bagi masyarakat melalui kontribusi yang diberikan dan menjadi pencitraan yang bagus untuk perguruan tinggi secara tidak langsung. Selain itu CSR untuk perguruan tinggi juga menjadi cara bersaing dengan perguruan tinggi lainnya. Secara implisit program CSR mengandung arah kemana suatu lembaga tersebut dipimpin, seperti apakah lembaga yang hanya berfokus pada kegiatan akademik atau lembaga yang yang berkontribusi pada pengembangan masyarakat (Topal, 2009). Pada akhirnya program-program ini juga akan membangun hubungan yang kuat antara perguruan tinggi dengan stakeholder nya termasuk kepada masyarakat (Goodwin dan Barlett, 2008). 
Berbeda dengan penelitian sebelumnya yang hanya membuktikan praktik CSR yang dilaksanakan oleh universitas tanpa menjelaskan perlunya untuk melaporkan CSR. Peneliti menjadi tertarik untuk membahas bagaimana pemberlakuan tata cara pelaporan CSR. Peneliti berpikir lebih dalam lagi, untuk tujuan apakah sudah tersedia standar laporan CSR? Tentunya laporan ini berguna bagi kemajuan dan pencapaian suatu organisasi atau kelompok tertentu. Peranan akuntansi dalam tanggung jawab sosial (CSR) untuk universitas tidak bisa dipisahkan. Pelaporan CSR menjadi salah satu aspek penting selain financial report di sebuah annual report. Berbeda dengan financial report yang memiliki standar pelaporan baku seperti IFRS (International Financial Reporting Standars). Pelaporan CSR pada umumnya masih bersifat sukarela dan pada akhirnya menimbulkan perbedaan kualitas pelaporan.

Pada tahun 2015 ini, muncullah sebuah komunitas baru yang disebut Masyarakat Ekonomi ASEAN (MEA). Pada dasarnya MEA bergerak pada fokus bidang ekonomi, politik, dan budaya antar sepuluh negara ASEAN. Peranan universitas sebagai institusi pendidikan menjadi salah satu faktor capaian dalam MEA. Hal ini juga telah didiskusikan karena universitas menjadi faktor utama bagi kesiapan Sumber Daya Manusia (SDM). Selain itu praktik tanggung jawab sosial (CSR) di ASEAN sendiri menjadi salah satu fokus utama sejak dibentuknya MEA tahun 2015 yang mempunyai tujuan dan cita-cita untuk menciptakan lingkungan yang damai, stabil, dan makmur. ASEAN menyadari sepenuhnya keperluan untuk menyesuaikan cara pandang agar dapat lebih terbuka dalam menghadapi permasalahan-permasalahan internal dan eksternal, meningkatkan solidaritas, kohesivitas, dan efektivitas kerjasama (Lemhanas RI, 2012). Praktik CSR di ASEAN menjadi salah satu fokus utama yang tercantum didalam ASEAN Socio-Cultural Community (ASCC) Blueprint tahun 2010-2015. 


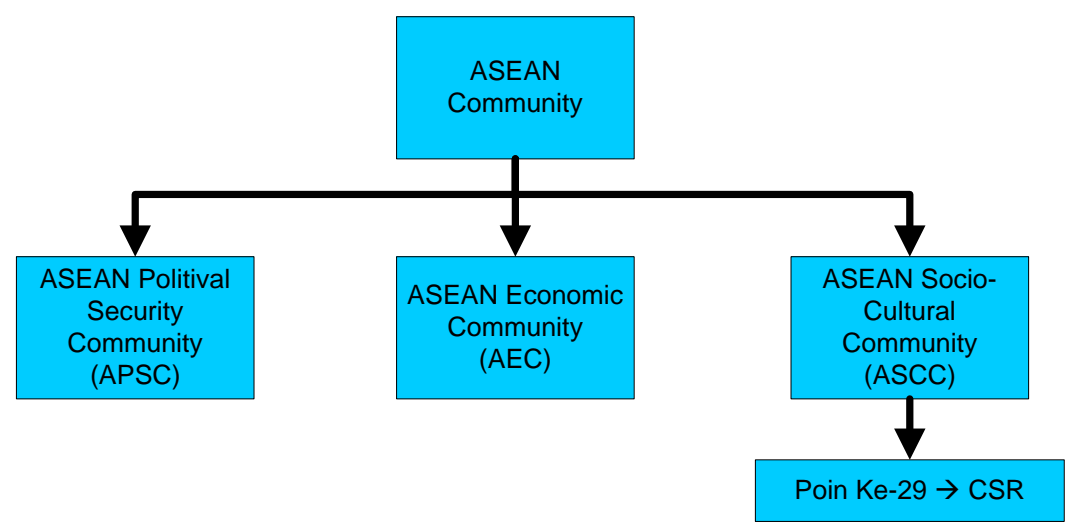

Gambar 1. Skema ASEAN Community dan hubungannya dengan praktik CSR Sumber: Lemhanas RI. 2012

Peran praktik tanggung jawab sosial (CSR) bagi Universitas khususnya di ASEAN menjadi sangat penting, karena CSR harus bisa diajarkan melalui program pendidikan sebagai usaha pengembangan sumber daya manusia (Human Development). Bahkan tanggung jawab sosial untuk universitas telah menjadi fokus utama yang dibahas dalam AUN-USR \&S, yaitu program-program tanggung jawab sosial untuk universitas yang dibahas oleh asosiasi universitas di ASEAN. Tetapi peneliti tidak bisa menggunakan dasar AUN-USR \&S sebagai fokus penelitian, karena belum tertulis didalam sebuah standar khusus.

Nejati dkk (2011) hanya membuktikan dan menemukan bahwa sepuluh universitas terbaik di dunia yang memang melaksanakan CSR atau tanggung jawab sosial terkait tujuan mencapai sustanability melalui analisis website. Ia belum membandingkan praktik CSR antara universitas dan belum mengukur persepsi terhadap stakeholder nya terutama untuk masyarakat sekitarnya. Untuk itulah dibutuhkan laporan CSR sebagai cara mengkomunikasikan praktik CSR dari universitas. Dengan adanya laporan CSR, stakeholder dapat membandingkan dan mengukur tanggung jawab sosial yang telah dilaksanakan universitas.

Research gap dalam penelitian ini adalah bagaimana melaporkan tanggung jawab sosial atau CSR dari universitas yang kemudian dapat ditunjukkan untuk kepentingan stakeholder khususnya masyarakat. Peneliti akan menggunakan ISO 26000 sebagai panduan untuk melaporkan tanggung jawab sosial universitas. Objek 
penelitian yang digunakan adalah National Univesity of Singapore dan Universitas Gadjah Mada. Kedua universitas ini juga memiliki kesamaan lokasi yang berada di Asia Tenggara atau negara ASEAN.

\section{KERANGKA TEORITIS}

\section{Social Accounting}

Social Accounting (akuntansi sosial) adalah proses mengkomunikasikan dampak sosial dan lingkungan dari tindakan ekonomi organisasi untuk kepentingan tertentu kelompok dalam masyarakat dan untuk masyarakat luas (Gray dkk, 1987). Social Accounting terkait juga pada akuntansi lingkungan pelaporan tanggung jawab sosial perusahaan, dan pelaporan non-keuangan dari sebuah organisasi. Social accounting umumnya digunakan dalam konteks bisnis, atau tanggung jawab sosial perusahaan (CSR), yang ditunjukkan bagi setiap organisasi, termasuk LSM, yayasan, dan lembaga pemerintah yang terlibat dalam hal akuntansi sosial.

\section{Corporate Social Responsibility (CSR)}

Konsep Corporate Social Responsibility (CSR) merupakan sebuah pendekatan modern dalam bisnis yang memberikan suatu tugas bagi perusahaan yang ingin menciptakan sustainbility harus memanfaatkan hubungan sosial dan lingkungan sekitarnya. Konsep CSR ini telah dipopulerkan oleh Elkington dengan konsepnya "Triple P", yang label tujuan adalah sebagai People (orang), Planet (Bumi), dan Profit (keuntungan) masing-masing (Elkington, 1997). Sedangkan definisi CSR menurut beberapa jaringan stakeholders, CSR sebagai mereka yang dapat mempengaruhi atau dipengaruhi oleh realisasi tujuan perusahaan, dan perusahaan ditantang untuk mengambil pendekatan yang seimbang untuk melakukan bisnis (Moratis, 2005). Serupa dengan definisi tersebut, Steiner dan Steiner (2009) menyatakan bahwa CSR adalah kewajiban perusahaan untuk menciptakan kekayaan dengan menggunakan cara yang tidak membahayakan untuk meningkatkan aset sosial dan lingkungan. 


\section{Corporate Social Responsibility (CSR) sebagai Triple Bottom Line (TBL)}

Menurut John Elkington, Triple Bottom Line adalah suatu alat praktis yang menjelaskan bagaimana CSR dapat digunakan sebagai alat akuntansi perusahaan yaitu sebagai suatu laporan ekonomi. Triple bottom line (disingkat TBL atau 3BL) adalah kerangka akuntansi dengan tiga bagian: sosial, lingkungan (ekologi atau) dan keuangan. Ketiga divisi juga disebut tiga P yaitu Planet (orang), Planet (bumi) dan Profit (keuntungan), atau yang lebih sering disebut sebagai "tiga pilar keberlanjutan". Manfaat dalam tiga bottom line telah berkembang di sektor nirlaba dan pemerintah. Banyak organisasi telah mengadopsi kerangka TBL untuk mengevaluasi kinerja mereka dalam konteks yang lebih luas (Slaper dkk, 2011).

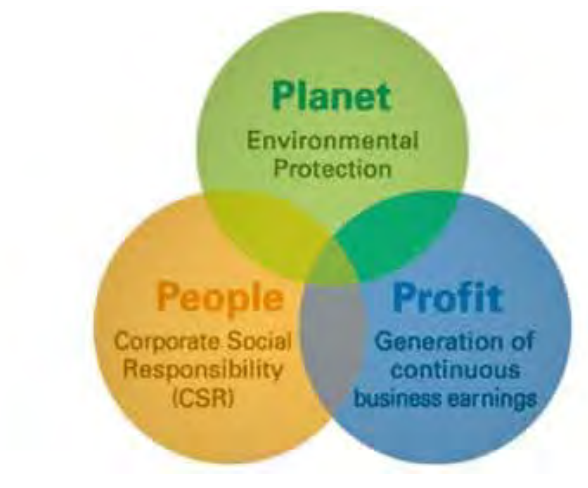

Gambar 2. Konsep Triple Bottom Line (TBL)

(Sumber: Elkington. 1997)

\section{Level Corporate Social Responsibility}

Menurut Dauman dan Hargreave (1992) dalam Hasibuan (2001), tanggung jawab perusahaan dapat dibagi menjadi tiga level, yaitu Basic Responsibility (BR), yang menghubungkan tanggung jawab yang pertama dari suatu perusahaan, yang muncul karena keberadaan perusahaan tersebut seperti perusahaan harus membayar pajak, memenuhi hukum, memenuhi standar pekerjaan, dan memuaskan pemegang saham. Kedua, Organization Responsibility (OR), menunjukkan tanggung jawab perusahaan untuk memenuhi perubahan kebutuhan stakeholder seperti pekerja, pemegang saham, dan masyarakat sekitarnya. Ketiga, Sociental Responses (SR), menunjukkan tahapan ketika interaksi antara bisnis dan kekuatan lain dalam masyarakat yang demikian kuat sehingga perusahaan dapat tumbuh dan berkembang 
secara berkesinambungan, terlibat dengan apa yang terjadi dalam lingkungannya secara keseluruhan.

\section{CSR-Universitas}

Dalam konteks universitas, penelitian sebelumnya menunjukkan bahwa lembaga pendidikan tinggi dapat menyebabkan "dampak signifikan terhadap lingkungan" (Jabbour, 2010). Oleh karena itu disimpulkan bahwa perguruan tinggi harus bertanggung jawab terhadap masyarakat dan stakeholder mereka. Stakeholders menyediakan organisasi dengan berbagai sumber daya seperti modal, pelanggan, karyawan, bahan dan legitimasi (Deegan, 2002). Sebuah studi baru-baru ini oleh Wright (2010), meneliti bagaimana kohort presiden dan wakil presiden di universitas

di Kanada mempunyai konsep pembangunan berkelanjutan untuk universitas dan peran perguruan tinggi ini dalam mencapai masa depan yang berkelanjutan, terutama terhadap isu-isu yang dihadapi universitas, dan hambatan untuk melaksanakan inisiatif keberlanjutan dari kampus. Dalam upaya lain, Nejati dkk (2010) meneliti isu kelestarian lingkungan di perguruan tinggi dengan memeriksa isi website Top 10 Universitas Terbaik Dunia. Perilaku kepeduliaan terhadap lingkungan yang paling sering dipraktikkan di antara 10 universitas ini berupa minimalisasi dampak lingkungan akibat kegiatan sehari-harinya

\section{CSR Reporting}

Menurut Termeulen (2011), praktik CSR yang telah dilaksanakan dapat dikomunikasikan melalui CSR Disclosures. Salah satu cara CSR Disclosure adalah membuat dalam bentuk CSR Report atau pelaporan CSR. Pelaporan CSR ini harus merangkum setiap kegiatan CSR yang telah dilaksanakan dalam periode tertentu. Menurut Dawkins dan Stewart (2003), perusahaan seharusnya membuat disclose informasi CSR-nya. Perusahaan menilai level dari laporan CSR, ketika tersedia sebuah pengukuran yang digunakan perusahaan tersebut. Menurut Termeulen (2011), suatu proses yang menyediakan informasi yang dibuat merupakan cara untuk mengungkapkan akuntabilitas sosial. 


\section{ISO 26000: Guidance Social Responsibility sebagai CSR Report Framework}

ISO 26000 merupakan sebuah panduan yang mendefinisikan apa yang disebut sebagai tanggung jawab sosial organisasi dan alasan perusahaan harus menggunakannya. ISO 26000 sebagai panduan sukarela (voluntary guidance), sehingga tidak dapat digunakan sebagai standar sertifikasi seperti ISO 9001:2008 dan ISO 14001:2004. Berdasarkan subjek utama ada tujuh core values yang menjadi pengukuran dalam ISO 26000. Pertama, Organizational Governance (sistem dimana sebuah organisasi membuat dan melaksanakan keputusan dalam mengejar tujuannya dimana dalam konteks tanggung jawab sosial memiliki karakteristik khusus menjadi subjek inti organisasi yang harus dilakukan dan dapat meningkatkan kemampuan organisasi dalam konteks sosial sehubungan dengan inti lainnya); Kedua. Human Rights (hak dasar semua manusia karena mereka adalah manusia, dengan keinginan intrinsik untuk kebebasan, perdamaian, kesehatan dan kebahagiaan, termasuk menghormati hak asasi manusia dan pengaruhnya di lingkungan); Ketiga, Labor Practices (mencakup semua kebijakan dan praktik yang berkaitan dengan pekerjaan yang dilakukan dalam, oleh atau atas nama organisasi); Keempat, The Environment (Keputusan dan kegiatan organisasi selalu berdampak pada lingkungan alam, tidak peduli di mana mereka berada, dampak tersebut mungkin terkait dengan penggunaan sumber organisasi hidup dan tak hidup, polusi dan limbah, dan implikasi untuk kegiatan organisasi, produk dan jasa di habitat alami).

Kelima, Fair Operating Practices (Praktik operasi yang adil menyangkut perilaku etis dalam transaksi organisasi dengan organisasi lain, termasuk hubungan antara organisasi dan lembaga pemerintah, serta antara organisasi dan mitra mereka, pemasok, kontraktor, pesaing dan anggota asosiasi yang mereka); Keenam, Consumer Issues (Organisasi yang menyediakan produk atau layanan kepada konsumen dan pelanggan memiliki tanggung jawab kepada mereka cosumers dan pelanggan.); Ketujuh, Community Involvement and Development (Keterlibatan dan pengembangan masyarakat yang baik pada bagian integral dari pembangunan berkelanjutan yang lebih luas). 
Untuk mengembangkan ISO 26000 menjadi sebuah kerangka pelaporan yang terintegrasi, dapat menggunakan konsep International Integrated Reporting $<\mathrm{IR}>$. Melalui rangkuman tertulis berjudul ISO 26000 and The International Integrated Reporting $<I R>$ Framework Briefing Summary, ditemukan bahwa sebuah laporan yang terintegrasi dapat dibuat dengan menggunakan delapan key elements yang terdiri dari:

1. Organizational Overview and External Environment - Apa yang dilakukan organisasi dan keadaan seperti apa yang mempengaruhi operasi dari organisasi tersebut?

2. Governance - Bagaimana struktur manajemen organisasi yang dapat mendukung kemampuan untuk menanamkan value pada jangka pendek, menengah, dan jangka panjang?

3. Business Model - Model bisnis apakah yang dijalankan organisasi tersebut?

4. Risk and Oppurtunities - Apa risiko spesifik dan kesempatan yang dapat mempengaruhi kemampuan organisasi untuk menanamkan value pada jangka pendek/ menengah/ panjang, dan bagaimana organisasi menghadapi hal tesebut?

5. Strategy and Resource Allocation - Kemanakah arah organisasi berjalan dan bagaimana cara mencapai tujuan tesebut?

6. Performance - Strategi objektif apakah yang dicapai oleh organisasi dalam satu periode dan hal apa saja yang dikorbankan/ dikeluarkan?

7. Outlook - Apa saja tantangan dan ketidakpastian organisasi yang mungkin terjadi dalam mencapai strategi dan apa saja implikasi potensial untuk model bisnis di masa depan?

8. Basis of preparation and presentation - Bagaimana organisasi dapat menentukan hal yang penting dalam integrated report dan bagaimana cara mengukur atau mengevaluasinya?

\section{Tujuan Pelaksanakan CSR untuk Universitas Berdasarkan ASEAN Socio- Cultural Community (ASCC) Blueprint}

Melalui penelitian ini, ASEAN Socio-Cultural Community (ASCC) ditetapkan sebagai tujuan pelaksanaan CSR untuk universitas. Sesuai yang telah dijabarkan 
sebelumnya, bahwa tanggung jawab sosial (CSR) telah menjadi cara untuk membangun komunitas ASEAN di bidang socio-economic melalui jabaran yang dijelaskan didalam dokumen ASCC Blueprint. Tujuan utama terdiri dari enam hal utama. Pertama, Human Development, meningkatkan kesejahteraan dan kehidupan rakyat ASEAN dengan menyediakan akses yang adil terhadap peluang pembangunan manusia dalam kegiatan pembangunan sosial-ekonomi. Kedua, Social Welfare and Protection, untuk meningkatkan kesejahteraan dan penghidupan masyarakat ASEAN dengan cara mengentaskan kemiskinan, memastikan kesejahteraan sosial dan perlindungan, membangun lingkungan yang bebas aman, dan meningkatkan ketahanan terhadap bencana dan menangani masalah pembangunan kesehatan.

Ketiga, Social Justice and Rights, untuk mempromosikan keadilan sosial dan mengutamakan hak-hak rakyat dalam kebijakan dan semua bidang kehidupan, termasuk hak-hak dan kesejahteraan kelompok yang kurang beruntung, rentan, dan terpinggirkan. Keempat, Ensuring Environmental Sustainability, untuk mencapai pembangunan berkelanjutan serta mempromosikan lingkungan yang bersih dan hijau dengan melindungi sumber daya alam untuk pembangunan ekonomi dan sosial. Kelima, Building the ASEAN Identity, identitas negara ASEAN adalah hal dasar artinya ASEAN sebagai kepribadian kita bersama, norma-norma, nilai-nilai dan keyakinan serta aspirasi sebagai satu komunitas. Keenam, Narrowing the Development Gap, untuk mencapai sasaran strategis yaitu memperkuat kerjasama dalam mengurangi kesenjangan pembangunan khususnya dimensi sosial dari pembangunan antara negara-negara ASEAN.

\section{METODE PENELITIAN}

Peneliti menggunakan metode content analysis yang akan meninjau semua halaman web terkait universitas (termasuk berita, media, halaman web departemen, dan lainnya). Untuk memperoleh validitas data dalam pengumpulan data yang berkaitan dengan kegiatan CSR yang dilakukan dua universitas, peneliti melakukan verifikasi sumber data berdasarkan nama situs web universitas yang sudah terdaftar 
di dalam Webometrics. Analisis data berdasarkan situs web resmi universitas yaitu National University of Singapore dan Universitas Gadjah Mada. Penelitian ini juga menggunakan analisis dan pengukuran dengan pedoman ISO 26000 yang memiliki tujuh bidang utama CSR yang meliputi tata kelola organisasi, hak asasi manusia, tenaga kerja praktik, lingkungan, praktik operasi yang adil, konsumen masalah, dan keterlibatan dan pengembangan masyarakat. Sedangkan untuk mendapatkan informasi dan data berkaitan dengan tata cara pelaporan CSR Universitas, peneliti menggunakan dokumen ISO 26000 and The International Integrated Reporting $<I R>$ Framework briefing Summary yang didapatkan dari website resmi ISO, dan membandingkan tujuan pelaporannya dengan dokumen ASCC Blueprint dari website http://www.asean.org. Dengan demikian verifikasi data yang diperoleh dapat dianggap valid dan data dari sumber yang diambil ini dapat diandalkan, sehingga peneliti akan mampu menghasilkan kesimpulan yang dapat diandalkan.

\section{HASIL DAN PEMBAHASAN}

\section{Gambaran secara umum CSR di ASEAN}

The ASEAN Foundation telah membentuk jaringan regional untuk program CSR yang bernama ASEAN CSR Network (ACN). ACN mempunyai tujuan untuk mengatasi kurangnya kerja sama regional dan informasi mengenai Corporate Social Responsibility (CSR) sejalan dengan tindakan yang sudah ditetapkan di dalam ASEAN Socio-Cultural Community Blue Print (ASCC) untuk tahun 2008-2015 pada 14th ASEAN Summit. ASEAN CSR Network (ACN) mendukung ASEAN SocioCultural Community Blue Print (ASCC) yang mencakup bagian dari tujuan strategis yang memastikan bahwa tanggung jawab sosial perusahaan yang tergabung dalam agenda perusahaan dapat memberikan kontribusi terhadap pembangunan sosialekonomi yang berkelanjutan di negara ASEAN. ACN memiliki tiga program utama yang dijalankannya yaitu Program Bisnis \& Anti-Korupsi, Program Bisnis dan Hak Asasi Manusia, Program Leveraging Business in ASEAN for Food Security and Sustainable Agriculture (LAB). 


\section{Gambaran Umum National University of Singapore (NUS) dan Universitas Gadjah Mada (UGM)}

Tabel 1. Gambaran Umum National University of Singapore dan Universitas Gadjah Mada

\begin{tabular}{|c|c|c|c|}
\hline Rank* & Nama Universitas & Negara & Deskripsi \\
\hline 1 & $\begin{array}{l}\text { National University of } \\
\text { Singapore (NUS) }\end{array}$ & Singapura & $\begin{array}{l}\text { Universitas terbaik di Singapura dengan peringkat dunia 100- } \\
150 \text { versi ARWU 2012. Motto nya adalah Towards a Global } \\
\text { Knowledge Enterprise atau Menuju Pengetahuan Perusahaan } \\
\text { yang Global. Kurikullumnya berbasis multi-disiplin dan } \\
\text { pengayaan lintas fakultas. Alumni NUS adalah orang yang } \\
\text { berpengaruh di dunia. }\end{array}$ \\
\hline 9 & $\begin{array}{l}\text { Universitas Gadjah Mada } \\
\text { (UGM) }\end{array}$ & Indonesia & $\begin{array}{l}\text { Universitas negeri sejak tahun 1949, merupakan kampus } \\
\text { pertama yang didirikan setelah Indonesia merdeka. Motto } \\
\text { UGM adalah "Memimpin Peradaban Bangsa" dijiwai nilai- } \\
\text { nilai budaya bangsa dari Pancasila. UGM telah menjadi } \\
\text { universitas riset terkemuka di Indonesia. Alumni UGM } \\
\text { adalah orang berpengaruh seperti Presiden Joko Widodo dan } \\
\text { Sultan Hamengkubowono X. }\end{array}$ \\
\hline
\end{tabular}

Keterangan: *ranking Webometrics tahun 2015 untuk wilayah Asia Tenggara.

\section{Penerapan CSR di National University of Singapore dan Universitas Gadjah}

\section{Mada Berdasarkan Konten Situs Website-nya}

Berdasarkan temuan dan analisis terhadap tanggung jawab sosial dari kesepuluh universitas terbaik se-ASEAN melalui isi konten dalam website-nya, ditemukan beberapa bukti bahwa universitas mempunyai peranan tanggung jawab sosial (CSR). Analisis ini menggunakan indikator dengan tujuh core values berdasarkan ISO 26000-Social Responsibility, yaitu Organizational Governance, Human Rights, Labor Practices, The Environment, Fair Operating Practices, Consumer (Student) Issues, dan Community Involvement and Development sebagai dasar pengukuran dan analisis. Kedua universitas tersebut mempublikasikan secara transparan dan memiliki akuntabilitas melalui fakta baik dalam bentuk berita online, artikel, grafik/ chart, video interaktif, ataupun laporan PDF yang dapat diakses oleh semua pengunjung website.

Untuk area core value pertama yaitu Organizational Governance, kedua universitas ini menunjukkan adanya akuntabilitas dari sebuah universitas didasarkan 
pada salah satu tujuan dalam social accounting yaitu bertanggung jawab kepada kelompok yang lebih luas dari pemangku kepentingan (stakeholders). NUS secara terbuka menyajikan laporan annual report berupa laporan keuangan dan kinerjanya. Transparansi menjadi hal yang utama bagi kedua universitas ini berupa data diri dari setiap pejabat universitas, visi-misi universitas, susunan organisasi, identifikasi organisasi, aturan yang ditetapkan universitas, sertifikasi universitas, ataupun kegiatan yang diberikan dalam sebuah kalender akademik.

Berdasarkan core values kedua yaitu Human Rights, kegiatan CSR mencakup diversity (keberagaman), health (kesehatan), dan partsipasi mewujudkan nilai perdamaian di dalam universitas. Kedua universitas ini juga memberikan cerminan keberagamannya atau Diversity, dimana NUS memiliki Lee Kuan Yew Public School yang mempunyai tujuan utama membangun hubungan masyarakat secara beragam. UGM juga mempunyai peranannya sebagai The Protector of Diversity Culture berlandaskan nilai Bhineka Tunggal Ika. Universitas menjamin kesehatan bagi para mahasiswa, staff, pensiunan, dan masyarakat sekitar melalui program asuransi. Kedua universitas ini juga melaksanakan riset ataupun konferensi untuk meningkatkan kemajuan dalam ilmu kesehatan. Salah satu contohnya UGM terlibat dalam riset/ penelitian Simposium Gizi Nasional 2012.

Universitas sebagai institusi pendidikan tinggi mempunyai tanggung jawab sosialnya kepada para karyawannya atau yang bisa dikategorikan dalam area core value ketiga yaitu Labor Practices. Kedua universitas memberikan peranannya dalam mengembangkan sumber daya manusia (Human Resource Development) melalui training, workshop, fasilitas pendukung (sport facility), career life-balance, seni budaya, staff club, medical, insurance, ataupun fasilitas khusus untuk penelitian dan riset bagi dosen.

Keputusan dan kegiatan sebuah organisasi selalu berdampak pada lingkungan alam (environment), tidak peduli di mana mereka berada. NUS berkembang melalui NUS Green Guide untuk melaksanakan program berkelanjutan terkait pengelolaan kertas, stationery, alat elektronik, plastik, air, dan tisu. NUS juga memiliki divisi yang bernama NUS-Office of Environmental Sustainability dan School of Design and 
Environment. Sedangkan UGM juga memiliki semboyan sebagai Green Campus sejak tahun 2011, dengan beberapa kegiatan budidaya lingkungan seperti Festival Grebeg Sampah tahun 2013.

Pada area core value kelima yaitu Fair Operating Practices, universitas mempunyai peranan penting untuk mencapai praktik operasi yang adil dalam kaitannya hubungan dengan pemerintah, perusahaan, dan masyarakat. Praktik operasi yang adil dari universitas berupa keterlibatan universitas dalam publik untuk mematuhi aturan dan sikap etis kepada aturan pendidikan pemerintah ataupun menerima kunjungan pemerintah untuk kegiatan peningkatan mutu dan kualitas pendidikan. NUS telah melaksanakan program The NUS Students' Union (NUSSU) Rag Day 2013 yaitu acara kerjasama dengan menteri pendidikan Singapore. Selain itu praktik operasi yang adil juga berupa keikutsertaan universitas untuk berkompetisi. UGM juga aktif untuk terlibat dan mengadakan kompetisi contohnya mengikuti lomba Fly Your Ideas (FYI)-Airbus.

Dalam area selanjutnya yaitu Consumer (Student) Issues, universitas menyediakan informasi yang bermanfaat dan berguna untuk calon mahasiswa dan mahasiswanya sekarang, melalui publikasi informasi yang jelas dan lengkap untuk calon mahasiswa ataupun mahasiswa terkait dengan admissions, program kurikullum, fasilitas atau kelebihan kampus, teknologi, dan informasi penting lainnya. Sejak tahun 2014, NUS menggunakan internal Blended Learning Online (iBLOC) untuk mengoptimal sistem teaching\& learning dan berfokus pada pendidikan-industri dengan program Innovation Generation (iGen) dan Industry Partnership Programme (IPP). Sedangkan UGM juga memfasilitasi pembelajaran jarak jauh dengan $e$ learning dan memiliki program internasional melalui Office of International Affairs of Universitas Gadjah Mada.

Untuk area core value yang terakhir ini yaitu Community Involvement and Development, universitas dapat terlibat dalam pengembangan komunitas mahasiswa dan masyarakat melalui program sosial yang mendukung pembangunan ataupun perbaikan secara berlanjut. NUS memiliki sebuah program yaitu The Community Engangement Program (CEP) Network, yang mempromosikan perhatian dan 
pemahaman perbedaan kepercayaan dan budaya dari komunitas mahasiswa NUS.

Sedangkan UGM memiliki komunitas sadar bencana alam yang disebut Bokomi dan

IKC.

Tabel 2. Kegiatan CSR Secara Umum yang Dilaksanakan National University of Singapore dan Universitas Gadjah Mada berdasarkan ISO 26000

\begin{tabular}{|l|l|}
\hline $\begin{array}{l}\text { Core Values } \\
\text { based } \\
\text { ISO 26000-SR }\end{array}$ & \multicolumn{1}{|c|}{ Kegiatan CSR Secara Umum yang Dilaksanakan Universitas } \\
\hline $\begin{array}{l}\text { 1. Organizational } \\
\text { Governance }\end{array}$ & $\begin{array}{l}\text { 1. Akuntabilitas berupa publikasi laporan tahunan ataupun agenda kegiatan. } \\
\text { 2. Transparansi untuk mempublikasikan data diri pejabat universitas, susunan organisasi, } \\
\text { identifikasi organisasi, visi-misi universitas, aturan dari universitas, sertifikasi dari } \\
\text { universitas, dan rencana atau berita terkait universitas. }\end{array}$ \\
\hline 2. Human Rights & $\begin{array}{l}\text { 1. Diversity atau keberagaman berupa berita atau artikel yang menunjukkan kebersamaan } \\
\text { mahasiswa baik dari perbedaan jenis kelamin, budaya, dan agama; serta kesempatan } \\
\text { Student Exchange sebagai wujud mencapai internasionalisasi. }\end{array}$ \\
2. Health/ kesehatan yang dijamin universitas menjadi utama bagi mahasiswa, staff, \\
pensiunan, dan masyarakat sekitar; disertai asuransi. Riset untuk kesehatan juga menjadi \\
fokus utama \\
3. Partisipasi menjamin kedamaian.
\end{tabular}

Sumber: website resmi National University of Singapore dan Universitas Gadjah Mada yang telah diolah.

Tata Cara Pelaporan Praktek Corporate Social Responsibility (CSR) yang Telah Dilakukan National University of Singapore (NUS) dan Universitas Gajah Mada (UGM)

Sejalan dengan penelitian yang telah dilaksanakan oleh Moratis dkk (2005), Nejati dkk (2010), dan Wijaya dan Krismiyati (2014) yang telah membuktikan bahwa 
tanggung jawab social (CSR) telah dilaksanakan oleh universitas. Penelitian ini juga melanjutkan penelitian yang dilaksanakan oleh Dawkins dan Stewart (2003), Douglas dkk. (2004), dan Termeulen (2011) untuk menemukan pelaporan tanggung jawab social (CSR) untuk organisasi non-profit khususnya universitas sebagai institusi pendidikan tinggi. Penelitian ini dilatarbelakangi karena pembangunan komunitas ASEAN yang perlu didukung melalui pengembangan sosio-kultur masyarakat dengan adanya tanggung jawab sosial (CSR) sesuai dengan ASEAN Socio-Cultural Community (ASCC).

Pelaporan CSR Universitas di ASEAN merupakan cara mengkomunikasikan praktik tanggung jawab sosialnya, berkaitan dengan ASEAN Socio-Cultural Community (ASCC) yang mempertimbangkan CSR sebagai agenda untuk berkontribusi mendukung sustainable socio-economic negara-negara ASEAN. Berdasarkan praktek tanggung jawab sosial (CSR) yang telah dilaksanakan National University of Singapore (NUS) dan Universitas Gajah Mada (UGM), kemudian dapat dibuat sebuah kerangka laporan CSR berdasarkan ISO 26000 dengan delapan key elements International Integrated Report $<\mathrm{IR}>$ Framwork.

Pada dasarnya kerangka pelaporan CSR yang telah dibuat ini masih bersifat voluntary disclosure, sehingga perlu adanya kesepakatan bersama untuk dapat mengkomunikasikan praktik CSR yang telah dilakukan dan diharapkan universitasuniversitas lainnya dapat menerapkan kerangka pelaporan yang seragam dan dapat dibandingkan. Tujuan jangka panjangnya dapat mengkomunikasikan CSR universitas dengan tujuan ASCC Blueprint yang merupakan salah satu pilar membangun komunitas ASEAN.

Tabel 3. Tata Cara Pelaporan Berdasarkan Framework ISO 26000 dengan Lensa $<$ IR $>$ Key-Elements

\begin{tabular}{|c|l|l|}
\hline No & $\begin{array}{c}\text { ISO 26000 Guidance of } \\
\text { Social Responsibility with } \\
<\text { IR> Key Elements }\end{array}$ & \multicolumn{1}{c|}{ Deskripsi } \\
\hline 1 & $\begin{array}{l}\text { Organizational Overview } \\
\text { and External Environment }\end{array}$ & $\begin{array}{l}\text { Universitas dengan tujuan visi-misi dari National University of } \\
\text { Singapore (NUS) dan Universitas Gajah Mada (UGM). }\end{array}$ \\
\hline 2 & Governance & Struktur dari kedua universitas dan fungsinya. \\
\hline 3 & Business Model & $\begin{array}{l}\text { menambah jumlah peminat calon mahasiswa yang akan masuk, dan } \\
\text { mendapatkan positive image }\end{array}$ \\
\hline
\end{tabular}




\begin{tabular}{|c|l|l|}
4 & Risk and Oppurtunities & $\begin{array}{l}\text { Risko dan kesempatan yang didapat setiap universitas ketika } \\
\text { melaksanakan CSR atau tidak melaksanakan CSR. }\end{array}$ \\
\hline 5 & $\begin{array}{l}\text { Strategy and Resource } \\
\text { Allocation }\end{array}$ & $\begin{array}{l}\text { Menyesuaikan arah dan tujuan universitas untuk kegiatan CSR yang } \\
\text { berdasarkan enam fokus utama ASCC Blueprint. }\end{array}$ \\
\hline 6 & Performance & $\begin{array}{l}\text { Kegiatan apa yang sudah dilaksanakan setiap universitas terkait } \\
\text { dengan enam fokus utama ASCC Blueprint. }\end{array}$ \\
\hline 7 & Outlook & $\begin{array}{l}\text { Identifikasi tantangan dan ketidakpastian berdasarkan enam fokus } \\
\text { tujuan utama ASCC Blueprint. }\end{array}$ \\
\hline 8 & $\begin{array}{l}\text { Basis of preparation and } \\
\text { presentation }\end{array}$ & $\begin{array}{l}\text { Menentukan informasi yang penting dalam laporan yang } \\
\text { menggunakan dua prinsip utama dalam ISO 26000 yaitu akuntabilias } \\
\text { dan transparansi. }\end{array}$ \\
\hline
\end{tabular}

Sumber: website resmi National University of Singapore dan Universitas Gadjah Mada yang telah diolah; Dokumen ASEAN Socio-Cultural Community (ASCC) Blueprint.

\section{KESIMPULAN DAN SARAN}

Berdasarkan hasil pembahasan dan analisis, telah ditemukan bahwa NUS dan UGM melaksanakan praktik tanggung jawab sosial (CSR) yang dilakukan secara berkelanjutan. Sebaliknya NUS dan UGM masih belum mengkomunikasikan praktik CSR nya dalam sebuah laporan yang terintegrasi. Laporan kegiatan CSR sangat penting untuk menunjukkan akuntabilitas sosial. Sebaliknya, pelaporan CSR sampai saat ini masih dalam bentuk voluntary disclose sehingga tidak ada standar global bagi universitas.

ISO 26000 sebagai panduan praktik CSR dan framework tata cara pelaporan kegiatan CSR memberikan pemikiran terintegrasi untuk melaporkan kegiatan CSR dari NUS dan UGM. Pemikiran terintegrasi ini dapat menghasilkan sebuah pelaporan yang terintegrasi. Melalui International $<\mathrm{IR}>$ Framework, disebutkan ada delapan key elements yang mendasari pembuatan laporan terintegrasi. Peneliti menggunakan delapan key elements ini untuk menunjukkan cara pelaporan kegiatan CSR dari NUS dan UGM yang dibentuk dalam sebuah kerangka laporan. Peneliti juga membandingkan secara jelas kerangka laporan CSR dari NUS dan UGM. Hasil analisis dari penelitian menunjukkan bahwa delapan key elements yang dapat dipakai oleh universitas-universitas lain dalam melaporkan kegiatan CSR-nya dan didasari tujuan strategis di dalam ASCC Blueprint. 
Penelitian ini memiliki keterbatasan karena tidak melihat dan menganalisa informasi yang bersifat private atau tidak dipublikasikan secara terbuka. Selain itu persepsi dari stakeholder hanya untuk masyarakat secara luas, karena fokus penelitian ini lebih pada upaya CSR universitas dalam mengembangkan nilai bersama dalam masyarakat di wilayah ASEAN. Penelitian ini juga bersifat kualitatif, artinya tidak menggunakan data kuantitatif seperti laporan keuangan universitas.

Pada saat penelitian ini ditulis, hanya menggunakan perbandingan praktik CSR universitas dengan tujuan ASEAN Socio-Cultural Community (ASCC) Blueprint yang masih berlaku hingga tahun 2015. Sebenarnya asosiasi universitas Asia Tenggara yang bernama ASEAN University Network (AUN) juga masih merancang sebuah pedoman khusus tentang CSR bagi universitas yang bernama University Social Responbility and Sustainability (AUN-USR\&S). Oleh karena itu, pada penelitian yang selanjutnya terkait peran dan komitmen CSR Universitas dapat menggunakan pendekatan lain yang berbeda.

\section{DAFTAR PUSTAKA}

ASEAN. 2009. ASEAN: Blueprint for the ASEAN Socio-Cultural Community (2009-2015). Asia News Monitor: Bangkok, Thailand.

Christensen P, Thrane M, Jørgensen TH, dan Lehmann M. 2009. Sustainable development: assessing the gap between preaching and practice at Aalborg University. International Journal Sustainable Higher Education, 10(1): 4-20.

Dawkins. J. dan Stewart L. 2003. CSR in stakeholder expectations: and their implication for company strategy. Journal of Business Ethics, 44, p. 185.

Deegan C. 2002. The legitimising effect of social and environmental disclosures-A theoretical foundation. Accounting Auditing Accountability Journal, 15(3): 282-311.

Douglas, A., Doris, dan J., Johnson, B., 2004, Corporate Social Reporting in Irish Financial Institutions. Total Quality Management Magazine 16(6), 387-395

Elkington, J. 1997. Cannibals with Forks: The Triple Bottom Line of 21st Century Business. Capstone, Oxford.

Goodwin, F.W. dan Bartlett, J. L. 2008. Public Relations and Corporate Social Responsibility (CSR) - Working Paper.

Gray, R.H., D.L Owen dan K.T. Maunders. 1987. Corporate Social Reporting: Accounting and accountability. Hemel Hempstead: Prentice Hall p. IX. 
Hasibuan, M. R. 2001. Pengaruh Karakteristik Perusahaan Terhadap Emiten di BEJ dan BES. Tesis S2 Magister Akuntansi Undip (Tidak dipublikasikan) pengungkapan Sosial (Social Disclosure) Dalam Laporan Tahunan.

International Organization for Standardization. 2009. ISO Management System Vol. 9 No. 5: ISO 26000 - Guidance on Social Responbility. Geneve: ISO Central Secretariat.

International Organization for Standardization.2015. ISO 26000 and the International Integrated Reporting $<I R>$ Framework briefing summary. http://www.iso.org/iso/iso_26000_and_ir_international_integrated_reporting_en__lr.pdf (diunduh tanggal $1 \overline{5}$ juni 2015 )

International Organization for Standardization. 2010. ISO 26000:2010 - Guidance on social responsibility. http://www.iso.org (diunduh 5 Mei 2015)

International Organization for Standardization. 2010. ISO26000:2010 Box 3, ISO 26000 and small and medium-sized organizations(SMOs). Geneve: ISO Central Secretariat.

Jabbour, CJC. 2010. Greening of business schools: a systemic view. International Journal Sustainability Higher Education, 11(1): 49-60.

Lemhanas RI. 2012. Peran Indonesia dalam Mewujudkan ASEAN Socio-Cultural Community guna mendukung Ketahanan Nasional. Jurnal Kajian Lemhanas RI, Edisi 14.

Moratis, Lars, Jeroen Hoff, dan Bert Heul. 2005. A dual Challenge facing management education: Simulation-Based Learning and Learning About CSR. Netherlands: CSR Academy dan Rotterdam University/HES School of Marketing Management Studies.

Nejati, Mehran, Azadeh Shafaei, Yashar Salamzadeh, dan Mohammadreza Daraei. 2011. Corporate Social Responbilities and Universities: A Study of Top 10 World Universities' Websites. African Journal of Business Management Vol. 5(2), pp. 440447.

Slaper, Timothy F dan Hall, Tanya J. 2011. The Triple Bottom Line: What Is It and How Does It Work?. Indiana Business Review. Spring 2011, Volume 86, No. 1.

Steiner, G dan Steiner J. 1997. Business, Government and Society - A Managerial Perspective. New York: McGraw-Hills.

Termeulen, Stephanie.2011.The Influence of Corporate Social Responbility Reporting on Reputation. Eramus University Rotterdam-School of Economics

Topal, R. 2009. CSR in Universities Around the World. Social Responsibility Research Network.

Wright T. 2010. University presidents' conceptualizations of sustainability in higher education. International Journal Sustainability Higher Education, 11(1): 61-73.

Wijaya, Lina Sinatra dan Krismiyati.2014. General Rule of Thumb of CSR Program to Increase Intake in Higher Education. Malegaon: Educational Research Multimedia \& Publications. 